\title{
Open Innovation Practices, Product Development and Business Performance in Manufacturing Firms
}

\author{
Sandra Yesenia Pinzón-Castro ${ }^{1}$, Gonzalo Maldonado-Guzmán ${ }^{2}$, Elena \\ Patricia Mojica-Carrillo ${ }^{3}$ and Rubén Michael Rodríguez-González ${ }^{4}$
}

\begin{abstract}
In the scientific literature on innovation, there is a growing interest of researchers and academics in the analysis and discussion of the phenomenon of open innovation, as well as in the documentation of the contribution of empirical evidence of the capacities of the development of new products. However, little is known about the relationship between open innovation practices, new product development, and business performance, which is why there is a call from researchers, academics, and industry professionals, for future guidance, studies in the analysis and discussion of these three constructs through large samples that allow generalization of the results obtained, for which this research has the main objective of filling this gap in the literature through an extensive review of the literature. Likewise, a selfadministered questionnaire was distributed to a sample of 460 manufacturing companies in Mexico, analyzing the data set through confirmatory factor analysis and structural equation models. The results obtained suggest that open innovation practices have significant positive effects on both the development of new products and the business performance of manufacturing companies in the automotive industry.
\end{abstract}

\section{JEL classification numbers: M31}

Keywords: Open innovation practices, Product development, Firm performance, Manufacturing firms.

${ }^{1}$ Universidad Autónoma de Aguascalientes, Centro de Ciencias Económicas y Administrativas, Departamento de Mercadotecnia.

${ }^{2}$ Universidad Autónoma de Aguascalientes, Centro de Ciencias Económicas y Administrativas, Departamento de Mercadotecnia.

3 Universidad Autónoma de Aguascalientes, Centro de Ciencias Económicas y Administrativas, Departamento de Mercadotecnia.

${ }^{4}$ Universidad Autónoma de Aguascalientes, Centro de Ciencias Económicas y Administrativas, Estudiante del Doctorado en Ciencias Administrativas.

Article Info: Received: March 24, 2021. Revised: April 21, 2021.

Published online: April 27, 2021. 


\section{Introduction}

Most of the research in the national innovation system, in an open economy where the resources of invention, innovation and manufacturing capacity are being developed on a global scale (Maggioni \& Del Giudice, 2011; Trequattrini et al., 2012a, b , 2014; Campanella et al., 2013a, b; Del Giudice \& Maggioni, 2014; SotoAcosta et al., 2015; Palacios-Marqués et al., 2015a, b), has basically focused on the analysis of networks of regional integration that have a significant impact on the economic performance of manufacturing companies and, more specifically, on business performance and innovation capacity (Furman et al., 2002). For this reason, the innovation potential of a given region or industry depends to a high percentage on the learning and management capacity of company managers, as well as technological and entrepreneurial skills (Della Peruta et al., 2018), since interactive learning and external collaboration generally stimulate the development of open innovation practices (Asheim et al., 2003).

In this context, Chesbrough et al. (2006: 174) showed that "since knowledge flows more easily to the closest entities, companies and organizations that work in collaboration networks that are geographically closer, are crucial in explaining the difference and effectiveness of open innovation in different regions or industries". However, these ideas are not truly clear in the scientific literature, because it is not specified to what extent the collaboration networks of manufacturing companies have to be regional or local, instead of being national or international, in order to improve the development of companies open innovation practices (Della Peruta $e t$ al., 2018), since the main presumption of the defenders of the regional economic development model is the existence of various commercial and non-commercial interdependencies that generally tend to operate in most parts of the country manufacturing companies on a regional scale (Asheim et al., 2003).

Thus, one of the essential elements that must be considered in the innovation system is the existence of different manufacturing companies that participate in the market with different business models, which creates a barrier for the creation of knowledge and promotion of innovation (Della Peruta et al., 2018). However, the generation of an appropriate synergy of collaboration between manufacturing firms is the most practical and effective element to raise the level of business performance and stimulate the improvement of processes that increase product development (Lombardi et al., 2014; Trequattrini et al., 2015). Therefore, it is possible to establish that open innovation practices allow interaction and exchange of resources to improve the development processes of new products, which creates greater competitive advantages for all participating companies, through the generation of new knowledge (Del Giudice et al., 2013a, b; Della Peruta \& Del Giudice, 2013). In this sense, the development of new or improved products and the business performance of manufacturing companies is not limited exclusively to the increase in costs and the lack of opportunities, but rather to the abilities of companies to generate and obtain the required knowledge. Both to operate properly, as well as to improve its innovation activities (Della Peruta et al., 2018). 
However, the empirical evidence of the relationship between open innovation practices, product development and business performance are relatively scarce, which is why it is possible to establish that this relationship can be considered as inconclusive (Rubera et al., 2016; Della Peruta et al., 2018). Therefore, this study contributes to the literature of open innovation practices, product development and the level of business performance, with the generation of new knowledge and the contribution of robust empirical evidence that allows filling the existing gap in the current literature.

Under this context, to complement and expand the existing limitation in knowledge, this empirical study establishes the following research question: what is the relationship between open innovation practices, product development and business performance in manufacturing companies? The rest of the work is structured as follows: in section 2, an extensive review of the literature is presented, and the research hypothesis is established; Section 3 introduces the research methodology; section 4 presents the analysis and interpretation of the results obtained and, finally, section 5 establishes the conclusions derived from the results obtained, the limitations and future lines of research.

\section{Preliminary Notes}

Chesbrough (2003) suggests that the traditional model of innovation in which the entire innovation process takes place within organizations, without any contact with the external environment before the products are introduced to the market, is not sustainable given the increase in the level of technology and changes in consumer tastes that generate a shorter product innovation cycle and an increase in R\&D costs (Rubera et al., 2016). These changes in market dynamics have increased interest in open innovation practices, since through open innovation, knowledge is generated that accelerates the innovation activities of manufacturing companies and expands the market for the use of the external knowledge (Chesbrough, 2006), through the offer of new or improved products to consumers that commonly have a high technological component (Rubera et al., 2016).

In this sense, open innovation practices are considered in the scientific literature as one of the essential strategies in manufacturing companies in different industries, including the automotive industry and the low-tech industry (Huston \& Sakkab, 2006). In addition, various researchers, academics and industry professionals have oriented their studies on the analysis and understanding of open innovation through case studies, for which they call for future research to carry out studies with large samples, whose results can be extrapolated to the entire manufacturing industry or a specific sector, so that open innovation practices are investigated and their relationship both with the development of new or improved products, as well as with the level of business performance (West et al., 2006; Ribstein et al., 2009).

Likewise, it is common to identify three critical gaps in the current scientific literature that limit the analysis and understanding of open innovation practices. First, an external collaboration should lead manufacturing companies to expand 
their knowledge base to significantly reduce the high dependence they have on some of their main suppliers and business partners (Prabhu et al., 2005; Almirall \& Casadesus-Masanell, 2010). Therefore, the real value of open innovation practices in companies does not lie in a simple increase in the number of new or improved products, but rather in helping manufacturing firms to introduce and commercialize new product categories in the different markets in which it participates (Rubera et $a l ., 2016)$, in such a way that it allows it to increase its level of business performance. Furthermore, new products do not necessarily have to be totally new to the market, but they are new to manufacturing firms (Crawford \& DiBenedetto, 2011), since it is suggested that the word "new" in product development should be defined. From the perspective of companies, because each of the manufacturing companies has to invest a certain number of resources for the development of new products (Sethi et al., 2012). Second, the knowledge-based vision of manufacturing companies suggests that external resources are combined with their internal capabilities, possibly determining better results, including a higher level of business performance (Katila \& Ahuja, 2002), therefore which, generally, the internal capacities that companies possess will determine a high percentage of the positive effects of open innovation practices on the level of business performance (Rubera et al., 2016).

However, a more detailed analysis of the scientific literature indicates that the internal capacities of manufacturing companies, possibly determine to a greater extent the openness of organizations to improve their innovation systems (Cohen \& Levinthal, 1990; Todorova \& Durisin, 2007). Third, a detailed review of the scientific literature indicates that open innovation has usually been used as a generic term to indicate any change related to innovation activities between manufacturing firms and the external environment (Rubera et al., 2016). However, open innovation practices can occur at different stages of the new product development process, and can also vary in content, the risks involved in developing products for new markets, and the speed at which new products become totally obsolete in the markets (Nambisan \& Sawhney, 2007).

Additionally, the knowledge generated within and outside of manufacturing firms is one of the most important assets that generate a significant increase in the business performance (Kogut \& Zander, 1992; Zander \& Kogut, 1995; Grant, 1996), since that according to the knowledge base generated in firms, the way in which companies create, acquire, assimilate and exploit knowledge will allow them both the generation of a potential increase in economic and financial resources, as well as the differentiation of their products with respect to those of its main competitors (Kogut \& Zander, 1992; Zahra \& George, 2002; Hult et al., 2004; Foss et al., 2013). For this reason, it is common to find in the literature that success in the integration of external resources involves two essential processes: acquisition and use of knowledge for the benefit of firms (Zahra \& George, 2002).

In this sense, the different levels of capabilities of manufacturing companies are generally an element that determines the heterogeneity in the propensity that organizations have in the search for existing knowledge in the external environment 
and resources related to activities. innovation (Todorova \& Durisin, 2007). Therefore, the existing differences between manufacturing companies in the adoption and implementation of open innovation practices are probably determined by the differences in the levels of their capacities (Rubera et al., 2016), since the different levels of capabilities of manufacturing companies determine the heterogeneity in the adequate use of existing external resources (Cohen \& Levinthal, 1990; Sorescu et al., 2003).

In this context, the capabilities of companies are considered essential for the development of new products, because it is a learning process for organizations during which manufacturing firms use their resources through open innovation practices for development or development. Improvement of their products (Leonard-Barton, 1992). For this reason, the development of new products is considered in the scientific literature as a process that is articulated in two macro stages: development and commercialization (Yli-Renko \& Janakiraman, 2008), including the generation of ideas in the development stage, the design of the concept, the development of the prototype and the market test, for which the information of the knowledge of the needs of consumers and technology is required, in such a way that allows manufacturing companies to turn their ideas into physical products that can be purchased by consumers (Rubera et al., 2016).

Likewise, there is theoretical and empirical evidence in the literature on innovation that to develop unique and successful products, manufacturing companies first need to know the needs of their consumers and, later, have the technical capabilities to act on these types of ideas (Danneels, 2002; Rubera et al., 2012). Therefore, it is possible to establish that the development or improvement of products is a basic process that articulates technology and consumer needs (Dougherty, 1992), for which the adoption of open innovation practices is required, that are related to technology and consumers (Rubera et al., 2016), since according to the capacities and abilities that companies possess for the development and exploitation of new or improved products, it will facilitate the improvement of the level of business performance (Vorhies \& Morgan, 2005; Krasnikov \& Jayachandran, 2008).

Regarding the commercialization stage, it generally involves the launch of the products to the market, the training of the sale of the products and the support of the sales (Ernst et al., 2010), and is commonly characterized by the different capacities that manufacturing firms have to reduce consumer barriers to the adoption of new or improved products (Rubera et al., 2016). In addition, the development of the product portfolio of manufacturing companies is carried out through the launch capabilities of new or improved products, which are defined as the organizational skills that facilitate the dissemination of products in the market (Talke \& Hultink, 2010), but these launch capabilities depend in a high percentage on the adoption and implementation of open innovation practices.

Thus, manufacturing companies require the knowledge generated in the market to allow the development or improvement of products in the same markets (LeonardBarton, 1992), otherwise, companies that do not have the ability to seek resources outside of them, and only consider internal resources, generally have a high 
dependence of their innovation activities on the availability of their resources (Rosenkopf \& Nerkar, 2001). However, the opening of manufacturing companies to external innovation systems allows them to acquire external resources (ideas and/or technologies) that facilitate the development of new or improved product categories, and significantly improve their different practices of open innovation (Ahuja \& Katila, 2001; Prabhu et al., 2005; Laursen \& Salter, 2006; Almirall \& Casadesus-Masanell, 2010).

Thus, considering the information previously presented, it is possible to propose the following research hypothesis:

H1: Open innovation has significant positive effects on product development.

In addition, with the adoption and implementation of open innovation practices, manufacturing companies can acquire both new ideas for the identification of those areas that may be more commercially important soon (Prabhu et al., 2005), as well as new technology that allows a new combination of product characteristics that in a particular way would be very difficult to carry out (Almirall \& CasadesusMasanell, 2010). Therefore, external resources allow manufacturing companies to turn them into innovative products only when they have a solid base of knowledge (Ahuja \& Katila, 2001; Katila \& Ahuja, 2002). For this, organizations need to significantly improve their innovation capacities, and they will only be able to do it through open innovation practices, which also has a significant positive effect on the level of business performance of manufacturing companies (Rubera et al., 2016). Likewise, the scientific literature establishes that open innovation practices improve $\mathrm{R} \& \mathrm{D}$ capabilities, which allows manufacturing companies to have the necessary structure for the use of external ideas and technologies that generate a higher level of business performance ( Rubera et al., 2016), on the contrary, those manufacturing companies that have only a low internal R\&D capacity are less likely to transform externally acquired resources into new or improved products (Sorescu et al., 2003; Todorova \& Durisin, 2007). Therefore, it is possible to establish that the increase in $\mathrm{R} \& \mathrm{D}$ capacities allows manufacturing companies to generate heterogeneous information, which improves the combination of different ideas and technologies that increase the level of business performance if they implement the practices of open innovation (Katila \& Ahuja, 2002).

Under this context, because of the adoption of open innovation practices, manufacturing companies can more quickly identify new technologies and ideas of consumer needs, which allow them not only to participate in innovation of new or improved products but beyond the current limits of organizations, but also to obtain a significant increase in the level of business performance (Rosenkopf \& Nerkar, 2001; Zhou \& Wu, 2010). Therefore, companies that adopt open innovation practices have greater possibilities of converting the different existing resources abroad into new or improved products, which will allow them to increase their level of business performance (Rubera et al., 2016). Thus, considering the information previously presented, it is possible to propose the following research hypothesis: 
H2: Open innovation has significant positive effects on business performance.

To answer the two proposed research hypotheses, an empirical study was carried out in the manufacturing companies of the Mexican automotive industry, implementing in a first phase of the study a qualitative research through which indepth interviews with three academics were applied from the innovation area and five entrepreneurs from the automotive industry. The results obtained in this first phase allowed the design of a survey to collect the information, which was reviewed by four academic experts in innovation and ten businessmen from the automotive industry, making minor adjustments to writing, appearance, and spelling. This type of qualitative studies is essential for the validation of the information when selfadministered questionnaires are applied, or they have already validated measurement scales (Bryman, 2016; Hair et al., 2016).

Likewise, the frame of reference that was considered relevant for this study was the business directory of the Mexican automotive industry, which had a registry of 909 firms as of November 30, 2018, the firms belonging to various organizations and local business chambers, regional and national, so the empirical study did not focus on a particular business group or association. In addition, the survey for the collection of information was applied to a sample of 460 firms selected by simple random sampling, with a maximum error of $\pm 4 \%$ and a level of reliability of $95 \%$, representing $50.6 \%$ of the total of the population and applying the survey during the months of January to March 2019.

Additionally, one of the most frequently presented problems in the scientific literature is how to measure innovation practices (Zhang et al., 2019), which requires researchers, academics, and industry professionals to define with the greatest precision measurement of this type of practice is possible. Thus, for the measurement of open innovation, an adaptation of the scale proposed by Van de Vrande et al. (2009), who considered that it can be measured through 7 items. In addition, for the measurement of product development, an extensive review of the literature was carried out and an adaptation to the scale proposed by Sorescu and Spanjol (2008) and Ruperta et al. was considered pertinent (2016), who considered that product development is feasible to measure through 4 items.

Finally, to measure business performance, the scale proposed by Bag (2014) was used, who measured this construct through 6 items. Finally, all the items on the open innovation, product development and business performance scales were measured using a five-point Likert-type scale, with $1=$ total disagreement to $5=$ total agreement as limits, since this type of measurement provides an excellent balance between the complexity of the responses of the interviewees and the analysis of the information collected. (Forza, 2016; Hair et al., 2016).

In addition, with respect to the evaluation of the reliability and validity of the open innovation, product development and business performance scales, the application of a Confirmatory Factor Analysis (CFA) using the maximum likelihood method with the support of the software EQS 6.2 was considered pertinent (Bentler, 2005; 
Brown, 2006; Byrne, 2006). Therefore, to measure reliability, Cronbach's Alpha and the Composite Reliability Index (IFC) (Bagozzi \& Yi, 1988) were used. Thus, according to the results obtained, all the values of the three scales are greater than 0.7 for both indices, which provides evidence of the reliability of the scales and justifies their internal reliability (Nunally \& Bernstein, 1994; Hair et al., 2014). In addition, as evidence of convergent validity, the results of the CFA indicate that all the items of the related factors are significant ( $p<0.001)$, and the size of all the standardized factor loadings are greater than 0.60 (Bagozzi \& Yi, 1988).

The results of the application of the CFA are presented in Table 1 and suggest that the measurement model provides a good fit of the statistical data $\left(S B-X^{2}=564.974\right.$; $\mathrm{df}=116 ; \mathrm{p}=0.000 ; \mathrm{NFI}=0.864 ; \mathrm{NNFI}=0.869 ; \mathrm{CFI}=0.888 ; \mathrm{RMSEA}=0.079$ ). In addition, Table 1 shows a high internal consistency of the constructs, in each case Cronbach's Alpha exceeds the value of 0.70 recommended by Nunally and Bernstein (1994). The CRI represents the variance extracted between the group of observed variables and the fundamental construct (Fornell \& Larcker, 1981), for which a CRI greater than 0.60 is considered desirable (Bagozzi \& Yi, 1988), in this study this value it is widely surpassed. The Variance Extracted Index (VEI) was calculated for each of the constructs, resulting in an VEI greater than 0.50 (Fornell \& Larcker, 1981), in this study 0.50 is exceeded in all factors. 
Open Innovation Practices, Product Development and Business Performance in...

Table 1: Internal consistency and convergent validity of the theoretical model

\begin{tabular}{|c|c|c|c|c|c|c|}
\hline Variable & Indicator & $\begin{array}{c}\text { Factorial } \\
\text { Load }\end{array}$ & $\begin{array}{l}\text { Value-t } \\
\text { Robust }\end{array}$ & $\begin{array}{c}\text { Cronbach } \\
\text { Alpha }\end{array}$ & CRI & VEI \\
\hline \multirow{7}{*}{ Open Innovation } & OIN1 & $0.721 * * *$ & $1.000^{\mathrm{a}}$ & \multirow{7}{*}{0.898} & \multirow{7}{*}{0.899} & \multirow{7}{*}{0.562} \\
\hline & OIN2 & $0.666^{* * *}$ & 13.669 & & & \\
\hline & OIN3 & $0.712 * * *$ & 14.628 & & & \\
\hline & OIN4 & $0.759 * * *$ & 15.592 & & & \\
\hline & OIN5 & $0.757 * * *$ & 15.549 & & & \\
\hline & OIN6 & $0.831 * * *$ & 17.040 & & & \\
\hline & OIN7 & $0.790 * * *$ & 16.226 & & & \\
\hline \multirow{4}{*}{$\begin{array}{c}\text { Product } \\
\text { Development }\end{array}$} & PDE1 & $0.671 * * *$ & $1.000^{\mathrm{a}}$ & \multirow{4}{*}{0.874} & \multirow{4}{*}{0.875} & \multirow{4}{*}{0.639} \\
\hline & PDE2 & $0.804 * * *$ & 14.989 & & & \\
\hline & PDE3 & $0.893 * * *$ & 16.079 & & & \\
\hline & PDE4 & $0.814 * * *$ & 15.138 & & & \\
\hline \multirow{6}{*}{$\begin{array}{c}\text { Business } \\
\text { Performance }\end{array}$} & BPE1 & $0.771 * * *$ & $1.000^{\mathrm{a}}$ & \multirow{6}{*}{0.926} & \multirow{6}{*}{0.927} & \multirow{6}{*}{0.681} \\
\hline & BPE2 & $0.759 * * *$ & 17.273 & & & \\
\hline & BPE3 & $0.860 * * *$ & 20.149 & & & \\
\hline & BPE4 & $0.891 * * *$ & 21.062 & & & \\
\hline & BPE5 & $0.887 * * *$ & 20.959 & & & \\
\hline & BPE6 & $0.770 * * *$ & 17.589 & & & \\
\hline
\end{tabular}

$S-B X^{2}(\mathrm{df}=116)=564.974 ; \mathrm{p}<0.000 ; \mathrm{NFI}=0.864 ; \mathrm{NNFI}=0.869 ; \mathrm{CFI}=0.888 ;$ RMSEA $=0.079$

${ }^{\mathrm{a}}=$ Parameters constrained this value in the identification process

$* * *=\mathrm{p}<0.01$

In addition, the discriminant validity of the theoretical model of open innovation, product development and business performance were measured by means of two tests, which are presented in Table 2. First, the confidence interval test is presented (Anderson \& Gerbing, 1988), which establishes that with a 95\% confidence interval, none of the individual elements of the latent factors of the correlation matrix has the value of 1. Second, the test of the variance extracted (Fornell \& Larcker, 1981), which establishes that the variance extracted from each pair of constructs is lower than its corresponding VEI. Therefore, according to the results obtained from the application of both tests, it is possible to conclude that both tests show sufficient evidence of the existence of discriminant validity. 
Table 2: Discriminant validity of the theoretical model

\begin{tabular}{|c|c|c|c|}
\hline Variables & Open Innovation & Product Development & Business Performance \\
\hline $\begin{array}{c}\text { Open } \\
\text { Innovation }\end{array}$ & $\mathbf{0 . 5 6 2}$ & 0.087 & 0.141 \\
\hline $\begin{array}{c}\text { Product } \\
\text { Development }\end{array}$ & $0.259-0.331$ & $\mathbf{0 . 6 3 9}$ & 0.177 \\
\hline $\begin{array}{c}\text { Business } \\
\text { Performance }\end{array}$ & $0.322-0.430$ & $0.361-0.481$ & $\mathbf{0 . 6 8 1}$ \\
\hline
\end{tabular}

The diagonal represents the Index of the Extracted Variance (IVE), while the variance (squared correlation) is presented above the diagonal, and the estimate of the correlation of the factors with 95\% is presented below the diagonal. Confidential interval.

\section{Main Results}

To answer the two hypotheses raised in this empirical study, a Structural Equation Model (SEM) was applied with the support of the EQS 6.2 software (Bentler, 2005; Byrne, 2006; Brown, 2006), analyzing the nomological validity of the theoretical model of open innovation, product development and business performance through the Chi-square test, by means of which the results obtained between the theoretical model and the measurement model were compared, obtaining non-significant results which allows establish an explanation of the observed relationships between latent constructs (Anderson \& Gerbing, 1988; Hatcher, 1994). Table 3 shows in greater detail the results obtained from the application of the SEM.

Table 3: SEM Results

\begin{tabular}{|c|c|c|c|}
\hline Hypothesis & Structural Relationship & $\begin{array}{c}\text { Standardized } \\
\text { Coefficient }\end{array}$ & $\begin{array}{c}\text { Robust } \\
\text { Value-t }\end{array}$ \\
\hline $\begin{array}{c}\text { H1: The higher the level of } \\
\text { open innovation, the higher } \\
\text { the level of product } \\
\text { development. }\end{array}$ & Open Innovation $\rightarrow$ Product D. & $0.303 * * *$ & 5.597 \\
\hline $\begin{array}{c}\text { H2: The higher the level of } \\
\text { open innovation, the higher } \\
\text { the level of business } \\
\text { performance. }\end{array}$ & Open Innovation $\rightarrow$ Business P. & $0.377 * * *$ & 7.169 \\
\hline $\begin{array}{l}S-B X^{2}(\mathrm{gl}=116)=564.962 ; \mathrm{p}<0.000 ; \mathrm{NFI}=0.864 ; \mathrm{NNFI}=0.869 ; \mathrm{CFI}=0.888 ; \text { RMSEA }=0.077 \\
* * *=\mathrm{P}<0.01\end{array}$
\end{tabular}

Table 3 shows the results obtained from the application of the SEM and it can be seen that with respect to hypothesis $\mathrm{H} 1$, the results obtained $\beta=0.0 .303 p<0.001$, indicate that open innovation practices have significant positive effects on the 
product development of manufacturing firms. Regarding hypothesis $\mathrm{H} 2$, the results obtained, $\beta=0.377 \mathrm{p}<0.001$, indicate that open innovation practices also have significant positive effects on the level of business performance of manufacturing companies. Therefore, it is possible to establish the existence of a close relationship between the practices of open innovation, product development and the level of business performance in the manufacturing companies of the automotive industry. The results obtained in this study have various practical implications both for managers and companies. A first implication derived from the results is that the data derived from the application of 460 surveys to the same number of companies, allowed a general analysis of the effects that open innovation practices exert both on product development and business performance in a particular business sector, the Mexican automotive industry, for which future studies will be pertinent to the analysis of these same constructs in case studies of success or in longitudinal studies. Therefore, from the point of view of the evolution of innovation, the results obtained indicate that open innovation practices are becoming one of the determining factors in the development of new or improved products and the level of business performance (Rubera et al., 2016).

A second implication emanating from the results obtained is that in the last two decades, the scientific literature on innovation was practically oriented to the analysis and discussion of the relationship between open innovation and business performance. However, there is little research that has focused on the effects of open innovation on product development, even as the development of new or improved products helps raise the bar of business performance. In addition, there are relatively few studies that have shown that open innovation practices significantly increase the number of new products introduced to the market (Leiponen \& Helfat, 2010), product innovation (Garriga et al., 2013), and the level of business performance (Laursen \& Salter, 2006), but the relationship between open innovation practices, the development of new or improved products and the level of business performance has not been analyzed.

A third implication of the results obtained is that the development of new products as an essential result of manufacturing companies is one of the essential roles of open innovation practices that has not been adequately investigated and analyzed in the scientific literature of the innovation, even when researchers, academics and industry professionals have recognized and provided empirical evidence that shows that open innovation practices have contributed to the creation of value, such as the development of new or improved products, which allows manufacturing firms to develop new product categories. Thus, the potential of open innovation practices can be realized and capitalized not only on the capacity of manufacturing companies to create new or improved products, but also on the improvement of results and the level of business performance.

A fourth implication derived from the results obtained is that it has been recognized in some studies published in the scientific literature on innovation that the external value of resources is a fundamental element for manufacturing companies (e.g., 
Cohen \& Levinthal, 1990; Todorova \& Durisin, 2007). However, there are few previously published studies that have clarified that the development of new products as a result of open innovation practices is much more complex than in traditional innovation. Therefore, this study provides empirical evidence that demonstrates that new or improved product development capabilities are relevant not only because they allow manufacturing firms to make more efficient external use of ideas and technology, but also because they improve systems, open innovation of manufacturing companies through the use of different external resources in the market.

A fifth and final implication emanating from the results obtained is the strong pressure that various environmental groups, consumers, suppliers, associations, communities and society in general are exerting so that manufacturing companies, including those that make up the industry automotive, to generate more environmentally friendly products and better sustainable development, for which one of the most viable alternatives considered by researchers, academics and industry professionals are open innovation practices (e.g. Della Peruta \& Del Giudice , 2013; Rubera et al., 2016; Della Peruta et al., 2018). However, for manufacturing companies to have greater possibilities of adopting and implementing open innovation practices, they require collaboration with other firms and organizations since several of them would not have the possibility of developing this type of activities alone.

\section{Conclusion}

The results obtained in this study have various conclusions, among the most relevant are the following. A first conclusion is that the theoretical model of the relationship between open innovation, product development and business performance have a high internal consistency, as it generates a good correlation between the three constructs, thus allowing the acceptance of the two research hypotheses raised. A second conclusion is that this same theoretical model presents an overview of open innovation practices (inbound and outbound), which generates better results than if it were analyzed separately. A third conclusion is that the studies previously published in the literature that relate these three constructs are relatively scarce, compared to those studies that have analyzed and discussed their conceptualization, which from our point of view lack a substantial contribution.

A fourth conclusion is that open innovation practices offer an alternative model to improve not only the sustainable innovation activities of manufacturing companies, but also product development, since open innovation practices allow companies to exchange information. ideas, technology, and products with other companies and/or organizations in a joint effort to maximize the returns on their investments and from the commercialization of their products. Therefore, this study provides empirical evidence of the effects that open innovation practices have both on the development of new or improved products and on the level of business performance, which enriches the analysis and debate about the value of the practices of open innovation 
in manufacturing companies and its relation to product development and business performance. A fifth conclusion is that the effects of open innovation practices on product development and business performance is a relatively recent topic in the literature on innovation, but it is also true that the relationship between these three important constructs is attracting the attention of researchers and academics, which allows us to conclude that it is an unfinished topic that is totally open to discussion. A sixth and final conclusion is that the analysis and discussion of the relationship between open innovation practices, product development and business performance in emerging economy countries, such as Mexico, has not been explored in the literature, for which this study provides robust empirical evidence that allows to conclude that open innovation practices are an essential activity that facilitates product development for organizations and improves the level of business performance.

This study has several limitations that are important to consider when analyzing and interpreting the results obtained. A first limitation is the use of measurement scales for open innovation, the development of new products and business performance, since these variables were measured through subjective indicators obtained from surveys (subjective data). For this reason, future studies will need to incorporate objective data from firms (e.g., number of collaborative projects with business partners, number of collaborative innovations, collaborative trademarks, number of new or improved product development, percentage of development of new products in collaboration), in order to verify if the results obtained differ or not from those obtained in this empirical study.

A second limitation is that open innovation may have better results if it is considered individually (inbound open innovation and outbound open innovation), or if some moderating variable of the particular characteristics of manufacturing firms is incorporated into the analysis (e.g., size, seniority, location), or managers (e.g., leadership, experience, skills). Therefore, in future studies it would be convenient to use one or some essential variables that moderate the effects that open innovation practices exert on the development of new or improved products and on the level of business performance of manufacturing companies in the automotive industry, to corroborate whether the results obtained differ or not from the results obtained in this empirical study.

A third limitation is that in this research work only seven indicators of open innovation practices were considered, as well as four indicators of the development of new products and six indicators of the level of business performance, for which in future studies it would be necessary that Other types of open innovation practices will be considered (e.g., research and development, technology development), in order to corroborate whether or not the results obtained are similar to those obtained in this study. A fourth and final limitation of these results is that the surveys were applied only to manufacturing companies in the automotive industry in Mexico, so in future studies it would be convenient to apply them in other sectors or in other countries to corroborate whether the results obtained differ, or not of the results obtained in this study. 


\section{References}

[1] G. Ahuja and R. Katila. Technological acquisitions and the innovation performance of acquiring firms: A longitudinal study, Strategic Management Journal, 22(3), (2001), 197-220.

[2] E. Almirall and R. Casadesus-Masanell. Open versus closed innovation: A model for discovery and divergence, Academic of Management Review, 35(1), (2010), 27-47.

[3] J. Anderson and D. Gerbing. Structural equation modeling in practice: A review and recommended two-step approach, Psychological Bulletin, 13(1), (1988), 411-423.

[4] B. Asheim, A., Isaksen, C., Nauwelaers and F. Tödtling. Regional Innovation Policy for Small-Medium Enterprises. Cheltenham: Edward Elgar Publishing. 2003.

[5] S. Bag. Impact of sustainable supply chain management on organizational performance: Mediating effects of leadership, Indian Journal of Management Science, 4(3), (2014), 10-251

[6] R.P. Bagozzi and Y. Yi. On the evaluation of structural equation models. Journal of the Academy of Marketing Science, 16(1), (1988), 74-94.

[7] P.M. Bentler. EQS 6 Structural Equations Program Manual. Encino, CA: Multivariate Software. 2005.

[8] T. Brown. Confirmatory Factor Analysis for Applied Research. New York, NY: The Guilford Press. 2006.

[9] A. Bryman. Social Research Methods. 5th ed. Oxford: Oxford University Press. 2016.

[10] B. Byrne. Structural Equation Modeling with EQS, Basic Concepts, Applications, and Programming. 2th edition. London: LEA Publishers. 2006.

[11] F. Campanella, M., Del Giudice and M.R. Della Peruta. The role of information in the credit relationship, Journal of Innovation and Entrepreneurship, 2(1), (2013a), 1-16.

[12] F. Campanella, M.R.., Della Peruta and M. Del Giudice. The role of sociocultural background on the characteristics and the financing of youth entrepreneurship: An exploratory study of university graduates in Italy, Journal of the Knowledge Economy, 4(3), (2013b), 244-259.

[13] H. Chesbrough. Open Innovation: The New Imperative for Creating and Profiting from Technology. Boston, MA: Harvard Business School Press. 2003.

[14] H. Chesbrough. The era of open innovation, Management Innovation Change, 127(3), (2006), 34-41.

[15] H. Chesbrough, W., Vanhaverbeke and J. West. Open Innovation: Researching and New Paradigm. Oxford: Oxford University Press. 2006.

[16] W.M. Cohen and D.A. Levinthal. Absorptive capacity: A new perspective on learning and innovation, Administrative Science Quarterly, 35(1), (1990), 128152. 
[17] M. Crawford and A. DiBenedetto. New Product Management. 10th edition. New York: McGraw-Hill Irwin. 2011.

[18] E. Danneels. The dynamics of product innovation and firm competences, Strategic Management Journal, 23(12), (2002), 1095-1121.

[19] M. Del Giudice and V. Maggioni. Managerial practices and operative directions of knowledge management within inter-firm networks: A global view, Journal of Knowledge Management, 18(5), (2014), 841-846.

[20] M. Del Giudice, E.G., Carayannis and M.R. Della Peruta. Unpacking Open Innovation: Highlights from a Co-Evolutionary Inquiry. New York: Palgrave MacMillan. 2013a.

[21] M. Del Giudice, M.R., Della Peruta and V. Maggioni. Collective knowledge and organizational routines within academic communities of practice: An empirical research on science-entrepreneurs, Journal of the Knowledge Economy, 4(3), (2013b), 260-278.

[22] M.R. Della Peruta and M. Del Giudice. Knowledge accumulation and reuse for spinning off firms from learning organizational: An individual knowledgebased perspective, International Journal of Social Ecology and Sustainable Development, 4(4), (2013), 20-29.

[23] M.R. Della Peruta, M., Del Giudice, R., Lombardi and P. Soto-Acosta. Open innovation, product development, and inter-company relationships within regional knowledge clusters, Journal of Knowledge Economic, 9(3), (2018), 680-693.

[24] D. Dougherty. A practice-centered model of organizational renewal though product innovation, Strategic Management Journal, 13(S1), (1992), 77-92.

[25] H. Ernst, W., Hoyer and C. Rübsaamen. Sales, marketing, and research-anddevelopment cooperation across new product development stages: Implications for success, Journal of Marketing, 74(5), (2010), 80-90.

[26] C. Fornell and D. Larcker. Evaluating structural equation models with unobservable variables and measurement error, Journal of Marketing Research, 18(1), (1981), 39-50.

[27] C. Forza. Surveys. In: C. Karlsson (Ed.), Research Methods for Operations Management. 2nd Ed. New York, NY: Routledge. 2016.

[28] N.J. Foss, J., Lyngsie and S.A. Zahra. The role of external knowledge sources and organizational design in the process of opportunity exploitation, Strategic Management Journal, 34(12), (2013), 1453-1471.

[29] J.L. Furman, M.E., Porter and S. Stern. The determinants of national innovative capacity, Research Policy, 31(6), (2002), 899-933.

[30] H. Garriga, G., von Krogh and S. Spaeth. How constraints and knowledge impact open innovation, Strategic Management Journal, 34(9), (2013), 11341144.

[31] R.M. Grant. Toward a knowledge-based theory of the firm, Strategic Management Journal, 17(S2), (1996), 109-122.

[32] J.F. Hair, W.C., Black, B.J., Babin and R.E. Anderson. Multivariate Data Analysis. 7th ed. Harlow, UK: Pearson Education. 2014. 
[33] J.F. Hair, M. Celsi, A., Money, P., Samouel and M. Page. Essentials of Business Research Methods. 3rd Ed. New York, NY: Routledge. 2016.

[34] L. Hatcher. A Step-by-Step Approach to Using the SAS System for Factor Analysis and Structural Equation Modeling, Cary, NC: SAS Institute Inc. 1994.

[35] G.T. Hult, D.J., Ketchen and S.F. Slater. Information processing, knowledge development, and strategic supply chain performance, Academy of Management Journal, 47(2), (2004), 241-253.

[36] L. Huston and N. Sakkab. Connect and develop: Inside Procter Gambles' new model for innovation, Harvard Business Review, 84(3), (2006), 58-66.

[37] R. Katila and G. Ahuja, Something old, something new: A longitudinal study of search behavior and new product introduction, Academy of Management Journal, 45(6), (2002), 1183-1194.

[38] B. Kogut and U. Zander. Knowledge of the firm, combinative capabilities, and the replication of technology, Organizational Science, 3(3), (1992), 383-397.

[39] A. Krasnikov and S. Jayachandran. The relative impact of marketing, researchand-development, and operations capabilities on firm performance, Journal of Marketing, 72(4), (2008), 1-11.

[40] K. Laursen and A. Salter. Open for innovation: The role of openness in explaining innovation performance among UK manufacturing firms, Strategic Management Journal, 27(1), (2006), 131-150.

[41] A. Leiponen and C.E. Helfat. Innovation objectives, knowledge sources, and the benefits of breadth, Strategic Management Journal, 31(2), (2010), 224-236.

[42] D. Leonard-Barton. Core capabilities and core rigidities: A paradox in managing new product development, Strategic Management Journal, 13(S1), (1992), 111-125.

[43] R. Lombardi, R., Trequattrini and M. Battista. Systematic errors in decision making processes: The case of the Italian Serie A football championship, International Journal of Applied Decision Sciences, 7(3), (2014), 239-254.

[44] V. Maggioni and M. Del Giudice. Affair di Famiglia. Milano: Egea. 2011.

[45] S. Nambisan and M. Sawhney. A buyer's guide to innovation bazaar, Harvard Business Review, 85(1), (2007), 109-118.

[46] J.C. Nunally and I.H. Bernstein. Psychometric Theory. $3^{\text {a }}$ Ed. New York, NY: McGraw-Hill. 1994.

[47] D. Palacios-Marqués, J.M., Merigó and P. Soto-Acosta. Online social networks as an enabler of innovation in organizations, Management Decision, 53(9), (2015b), 1906-1920.

[48] D. Palacios-Marqués, P., Soto-Acosta and J.M. Merigó. Analyzing the effects of technological, organizational and competition factors on web knowledge exchange in SMEs, Telematics and Informatics, 32(1), (2015a), 23-32.

[49] J.C. Prabhu, R.K., Chandy and M.E. Ellis. The impact of acquisitions on innovation: Poison pill, placebo, or tonic? Journal of Marketing, 69(1), (2005), 114-130.

[50] D.J. Reibstein, G., Day and J. Wind. Is marketing academia losing its way? Journal of Marketing, 73(4), (2009), 1-3. 
[51] L. Rosenkopf and A. Nerkar. Beyond local search: Boundary-spanning, exploitation, and impact in the optical disk industry, Strategic Management Journal, 22(4), (2001), 287-306.

[52] G. Rubera, D., Chandrasekaran and A. Ordanini. Open innovation, product portfolio innovativeness and firm performance: The dual role of new product development capabilities, Journal of the Academy of Marketing Science, 44(1), (2016), 166-184.

[53] G. Rubera, A., Ordanini and R. Calantone. Whether to integrate R\&D and marketing: The effect of firm competence, Journal of Product Innovation Management, 29(5), (2012), 766-783.

[54] R. Sethi, Z., Iqbal and A. Sethi. Developing new-to-the-firm products: The role of micropolitical strategies, Journal of Marketing, 76(2), (2012), 99-115.

[55] A. Sorescu and J. Spanjol. Innovation's effect on firm value and risk: Insights from consumer package goods, Journal of Marketing, 72(2), (2008), 114-132.

[56] A. Sorescu, R.K., Chandy and J.C. Prabhu. Sources and financial consequences of radical innovation: Insights form pharmaceuticals, Journal of Marketing, 67(1), (2003), 82-102.

[57] P. Soto-Acosta, S., Popa and D. Palacios-Marqués. E-business, organizational innovation and firm performance in manufacturing SMEs: An empirical study in Spain, Technological and Economic Development of Economy, 22(6), (2015), 885-904.

[58] K. Talke AND E. Hultink. Managing diffusion barriers when launching new products, Journal of Product Innovation Management, 27(4), (2010), 537-547.

[59] G. Todorova AND B. Durisin. Absorptive capacity: Valuing a reconceptualization, Academy of Management Review, 32(3), (2007), 774786.

[60] R. Trequattrini, V., Formisano, G., Russo and R. Lombardi. Microcredit, asymmetric information and start-ups: An Italian case study, African Journal of Business Management, 8(16), (2014), 660-670.

[61] R. Trequattrini, R., Lombardi and M. Battista. Network's analysis and football team performance: A first application, Team Performance Management: An International Journal, 21(1/2), (2015), 85-110.

[62] R. Trequattrini, G., Russo and R. Lombardi. Network governance: Organizational and legal profiles, Corporate Ownership \& Control, 9(4), (2012a), 346-350.

[63] R. Trequattrini, G., Russo and R. Lombardi. Defining business network, International Journal of Business Research and Management, 3(1), (2012b), 29-34.

[64] V. Van de Vrande, J.P., De Jong, W., Vanhaverbeke and M. De Rochemont. Open innovation in SMEs: Trends, motives and management challenges, Technovation, 29(6/7), (2009), 423-437.

[65] D.W. Vorhies and N.A. Morgan. Benchmarking NPD capabilities for sustainable competitive advantage, Journal of Marketing, 69(1), (2005), 80-94. 
[66] J. West, W., Vanhaverbeke and H. Chesbrough. Open innovation: A research agenda. In Chesbrough, H., Vanhaverbeke, W and West, J. (Eds.), Open Innovation: Rearching a New Paradigm. Oxford: Oxford University Press. 2006.

[67] H. Yli-Renko and R. Janakiraman. How customer portfolio affects new product development in technology-based entrepreneurial firms, Journal of Marketing, 72(5), (2008), 131-148.

[68] S. Zahra and G. George. Absorptive capacity: A review, reconceptualization, and extension, Academy of Management Review, 27(1), (2002), 185-203.

[69] U. Zander and B. Kogut. Knowledge and the speed of the transfer and imitation of organizational capabilities: An empirical test, Organization Science, 6(1), (1995), 76-92.

[70] D. Zhang, Z., Rong and Q. Ji, Green. Innovation and firm performance: Evidence from listed companies in China, Resource, Conservation \& Recycling, 144(1), (2019), 48-55.

[71] K.Z. Zhou and F. Wu. Technological capability, strategic flexibility, and product innovation, Strategic Management Journal, 31(5), (2010), 547-561. 